


\title{
SILENT SPRING TO CLIMATE REBELLION A BRIEF HISTORY OF CIVIL DISSENT OVER THE LAST SIXTY YEARS: THE CONTINUITY OF DREAD, AND WHAT IS A.R.T. FOR?
}

\author{
Adrian Hall
}

This short essay is based, on a simple premise: that we as humans, do have to take a responsibility to our environment on behalf of our progeny, and that that should be an immediate initiative. We should no longer tolerate the poisoning of the earth, nor air, nor waters, nor should we be affecting the natural evolution of the flora and fauna which form our world. We are at a point of crisis where unchecked commercial greed, and inequity at a gigantic ratio is responsible: far too much for too few: far too much inequity and ignorance. Scientific evidence has been available for decades, that humans are irrevocably heating the planet, primarily by burning fossil fuels. This has caused species of everything - to be so affected that extinction is escalating. As Rachel Carson did around nineteen- sixty, I first noticed the absence of particular creatures but only over the last fifteen years, and then discovered the multitudinous tragedy of the natural world in the twentieth century being compounded exponentially in the twenty-first. Though I have and do campaign on behalf of individual species, through a study of ecology, realising the relationship of things to each other, the overwhelming tragedy has been revealed as a totality of negative forces, effecting a totality of individual tragedies. I also considered the concomitant history of Dread in the late 20th. Century, and choose to mention some contemporary heroes who generate optimism through integrity and action.

A thread of these thoughts was that the overwhelming Dread-of-the-future which affects younger persons, has a history. Greta Thunberg happily, is a remarkable young woman continuing and extending conscientious civil dissent, while circumstantially harnessing the technology of her generation to thoroughly affect the twenty-first Century. Significant history though is within living sight, and worth knowing because it offers hope, and means of offsetting impending disaster. There is a continuum of insanity with peoples who recklessly threaten the existence of the human race. In the decade following nineteen-fifty, there was a vivid shadow of the Second World War. In Europe and the U.K., casualties of that war were everywhere to be seen on the streets. Austerity was ensured by rationing, profiteering discouraged by retail price maintenance. The conclusion of World War Two by the use of nuclear weapons, showed that hitherto impossibly destructive powers could at any time be unleashed. Tensions escalated with Cold War gamesmanship. So "putting aside childish things" for me, in the 1950's and 1960's, was about International Socialism in a pre-Thunberg age, and the Campaign for Nuclear Disarmament.

In the nineteen-fifties after serving on the Nuremberg War Crimes Commission, Bertrand Russell - mathematician and philosopher became prominent in the Campaign for Nuclear Disarmament, together with Pat Arrowsmith and Hugh Brock, editor of Peace News. The 40 mile Aldermaston Marches to London became annual events. A conscientious objector during the Second War and ex-R.C.A. student, Gerald Holtom designed the C.N.D. symbol. He said, "I was in despair, deep despair. I drew myself: the representative of an individual in despair, with hands outstretched palm outstretched outwards and downwards in the manner of Goya's peasant before the firing squad." He formalised the drawing into a line with a circle around it. The letters C - N - D from the 
semaphore alphabet were contained within that depiction. The Peace Sign remains, crossing all kinds of categories of belief and understanding, but is one whose essential meaning remains.

"Silent Spring" by Rachel Carson' was published in September 1962. She had written extensively and poetically from her cottage home about marine life as a marine-biologist. One who had never been under water until she had become very famous, and then only a tentative once, near her home. Carson had alerted the public and reversed the position of industrial chemical companies on the haphazard use of among other chemicals, dichlorodiphenyltrichloroethane. I have vivid memories as a child of the smell, and of taking turns before bed to drench the flat where we lived in Malta by pumping out commercial fly-killer from the Flit-gun.

No hydro-carbons however, with a tin pump spray-gun. On opening the doors of the living area in the morning, my first job was to sweep up the scores of large damp, dead flies off the tiled floor, still reeking and wet from D.D.T.

Almost single handedly Rachel Carson reversed the position of mighty chemical companies on the haphazard use chemicals. She had noticed the decreasing bird-songs around her home, over the years and traced the root cause to the pesticide poisoning of the land by DDT, which had been developed to combat mosquitoes and malaria, in the Second World War. A cycle of poisoning was revealed to Carson, and she made that cycle public. From the earth to the plant-life to the animal life to avian species, and into the ground waters then into the sea, where other habitat and creatures were affected. The ubiquitous use of that deadly chemical eventually ceased - against huge and persistent industry resistance. In many countries now it is totally banned. This was a point of individual awareness and horror, whereby change was effected through science and scrutiny from realisations of a lone individual, in the land and at the time of "Mad Men" oblivion. A high time in self-congratulatory American industrial-business culture: of Levitt-Towns and the expanding car industry. With production of every 'labour-saving device', capitalism in the United States, became a disproportionate bloat. The previous working-class through expansion in industry and commerce, became very much the white, middle-class. Television as a nascent phenomenon was able to magnify all these novel wonders without question, and make them desirable with a jingle.

In parallel to giddy consumerism, Dread was already prevalent. Of radiation poisoning, and supremely destructive explosive force, for common discourse included references to nocturnal nightmares of global nuclear war. Psychotherapies proliferated International relations were as factious as now, and there was a concern over the "balance of power", muscle-flexing being the dominant mode. That dread came to a head when Russia built Cruise missile sites in Cuba, pointing towards The United States, following the "Bay of Pigs" invasion incident in 1961. A failed invasion by exiled Cubans covertly funded and organised by the United States, was followed the next year by the Cuban missile crisis of 1962. This was the moment during the Cold War when the two superpowers: the United States and the Soviet Union came almost to nuclear war. Secret communications and miscommunications which played out between the White House and the Kremlin made the crisis a unique event. President Kennedy faced down the Russians and ignored the pressures of General Curtis LeMay, he was urging a pre-emptive nuclear strike.

Those Russian missiles, pointing at the U.S. were removed from Cuba after a thirteen day staring contest.

In the United States it became commonplace for even lower middle-class people, to build bomb-shelters in, or around, or under their homes; cities planned against fallout, and built bunkers for executives. Civil paranoia over threats of global nuclear warfare became the new normal. These events and tensions escalated and were followed by the assassination of the President and a series of other murdered high profile politicians, black leaders, and actual assassins. Civil Rights became an eruption and an obvious urgency as so it remains, as do other parities. The Vietnam War continued with American intervention. There were courageous and dangerous civil rights marches in the American Southern States. Into the Seventies in Europe the Cold War simmered, wars continued as a global habit, as colonised countries shook off the shackles to become independent, others consolidated. Anti-Vietnam War marches erupted everywhere. Capitalism thrives with armed conflict, fossil fuel industries also grow. Since the thirties Los Angeles was designed to grow without consideration of public transport, and grew expressly as a city for 
the automobile and the expressways. Car culture thrived everywhere - but in L.A., legendary traffic smog became thick enough to cause sore eyes, and lung diseases across the whole city.

In the mid-late sixties radio alerts were called on the morning news to warn susceptible persons to stay indoors on that day. Children too were warned to stay indoors during a 'Smog Alert'. To drive 35 miles from the San Gabriel Mountains down into Burbank and across the city to U.C.L.A. where I was teaching, was akin to submerging into a mud-grey morass, which would cause immediate eye and lung irritation the deeper downhill one drove into the San Fernando Valley. This became a source of strange pride for residents, a rite of passage which had to be endured by visitors until their sensitive tissues became inured. Phlegmatism on a heroic scale, akin to boasting of survival after warfare. In the twenty-first century, sixty years later, similar conditions are the norm in major cities everywhere. Disastrous pollution become rights of passage to be endured by new generations despite the lessons of history. But beyond personal jeopardy, it has become clear that this lies behind the changes of climate temperature, and this is responsible for most of the extinction tragedies in our century. So to concentrate on small batches of species data is to miss the point; not only the whales, the dolphins and the polar bears, but all of us mammals are in jeopardy and the horses we ride in on.

In the nineteenth century European colonialists thoroughly destroyed gargantuan numbers of birds in particular - under the aegis of science, though boosting fashionable hat and clothing trades. Those figures at this only slightly more aware time, are mind boggling - even the New Zealander for whom the Buller River was named and a species of local Mollymawk, slaughtered hundreds and hundreds of birds every day on expedition. 'Cataloging' meant capture and kill even to the last survivors. Thousands of Rockhopper Penguins were slaughtered at one time, regularly, simply for their small bright yellow plumes, which went back to Europe for use in the hat trade. The after-effects of that slaughter were invisible to scientists on the other side of the globe, though museums were popularly stuffed with cases and cases of stuffed creatures, from rodents to primates to mammals and large insects, little insects in drawers. Every thing which moved or crawled. The Victorians had a curious mind and an insatiable thirst for animal novelty. The most prominent contemporary exponent of the Victorian hunting style is a son of the current American President, who also has a fetish for firearms of a military capacity. He has no military experience, but he has proudly killed an elephant to cut off the tail with a Buck knife, and recently obtained a seldom granted licence to kill a Kodiak bear in Alaska. In the twenty-first century with everything we know and is available to us, there are those people who choose to remain willfully, even criminally ignorant simply for the sake of affluent egotistic destruction.

This though was the style in the nineteenth century for all the young adventurers with aspirations toward the Royal Society in London - which presented such science discovery activities as fashionable knowing-entertainment. There is a Royal Society of New Zealand in 2020. Interestingly, that society made no distinction between the natural sciences and the engineering sciences. Such public excitement also famously developed the galumphing, voracious use of fossil fuel as coal- burning steam power. Pure smoke, to be later replaced by pollution from the automobile and petroleum industries, the most significant contributor to the Climate Crisis and species annihilation. Not just the cuddly ones, the cute ones, but the essential ones for the growth of food-stocks, such as humble honey bees and other pollinators. We now can see and understand all kinds of inter-relationships enough to have a clear view towards the destruction of the Homosapiens species itself. This is catastrophe over-reaching all borders, this is where nationalism as a notion, fails.

When ecological systems are weakened to the point of re-structuring, as they are with new migration patterns emerging, or starvation, then unexpected hazards arise in terms of disease amongst animals and humans. Viruses are appearing at a worrying rate, new and deadly, and ancient and unknown, emerging from melting glaciers and from new interactions with animals. With the excessive mobility of humans across the globe and animals too, we learn that viruses move too. Who could have predicted a bat and the pangolin, introduced through trade for arcane beliefs in medicine in another continent, could maybe start another pandemic? 
With science spectacularly improving useful knowledge, there become proliferating unknowns, most mysterious are the viruses, which are even debatable as life forms. Our lax responsibility; in recognising and processing available data at the start of what shall be serial pandemics, is fluorescent. Credit is due to Bill Gates of Microsoft predicting from available science data in 2015 the dire need to prepare for a succession of coming pandemics, learned from the Ebola and SARS outbreaks, none of which had then touched urban areas. His scientific facts were presented in person to the newly elected President of the U.S. in 2016, as being the most urgent issue for which the World should be preparing...

While throughout world history significant change took a significant time to happen, with the pressure of rapidly escalating climate change, newer technologies, and our own eyes, we can witness in real time visible physical changes. Can Mount Everest really be getting smaller? What has happened to the glaciers on Aoraki?

Why did nobody seriously remark upon those huge ice-bergs which propelled by the warm southern current, were carried north in 2004, just east of the Otago Peninsula? Certainly they were noticed, as use was made of helicopters to carry wedding parties out to them for chilly nuptial celebrations, as the 'bergs entered warmer waters ready to turn turtle.

Warmer climate has also caused opportunistic shifts of mosquitoes to new breeding regions to find newly accessible hosts. Local yellow eye penguins for instance die of avian malaria and diphtheria, and are scarce to the point of extinction. Hotter climate sustained for longer periods gives the continent of Australia, bush fires beyond experience. And through this, and through new media we have been able to view close up, the destruction of cuddly koalas, plus the whole ecology of tropical and sub-tropical forest, from continent to continent. Add to this the long- time salinisation of for example, the Australian Murray River, replicated worldwide in similar conditions and circumstances and we can compile a planet-size list of criminal ignorance toward habitat, and creatures great and small.

Climate Crisis is quietly making the most unimaginable changes to nature.

The Guardian reports that the romance bird of John Keats, the nightingale, is unlikely to continue the long migrations which have been nature for it, as its wing length is shortening, and the clutch size of its eggs is diminishing. More of those birds are choosing not to make their 7,000-mile annual migration between Africa and Europe due to increasingly severe summer droughts. As numbers of marine mammals are slaughtered without regard for tomorrow, fish stocks are depleted through bigger and bigger and more destructive fishing methods. ${ }^{2}$ Giant trawl nets scour the ocean floor of kelp forests, destroying and depriving innumerable fish- species of breeding habitat. Those kelp forests also significantly off-set atmospheric carbon-dioxide from our highway traffic. Our local Yellow Eye Penguins have three choices for their imminent extinction: to starve, as did another one I retrieved today from the beach, or die of avian malaria, or diphtheria.

There is no thought by industries of the need to replenish or sustain, by the common sense use of marine reserves to allow creatures to breed and replenish the oceans. Industry proponents are at loggerheads with ecologists and politicians weakly try to mitigate. There has to be an informed balance; sustainability has been a clichéd term in bureaucracy for thirty years now, useful for only a limited effect because of limited understanding, but we are at a point where a plenitude of scientific data is available and should be guiding the debate. There is no need to look to foreign parts and we have to start at home, and we do have to support activists and lobby on a global scale. The inter-relatedness of things on Earth is obvious if it is studied, so too are human crimes of negligence, ignorance, causality and irresponsibility. We should have Dread, and those of us with grandchildren will know this Dread well.

A likely symbol for our time, as powerful as that of the Campaign for Nuclear Disarmament way back when, is possibly to be that designed for Extinction Rebellion. The symbol of Extinction Rebellion is a white on black stylised hourglass, all angles around a central ' $X$ '. "Climate Emergency' is the cry. Extinction Rebellion is a global environmental movement with the stated aim of using nonviolent civil disobedience to compel government action, in trying to avoid more severe destruction of the climate system, biodiversity loss, and the risk of social and ecological collapse. 
Roger Hallam in the U.K. believes the world has only ten years until mass starvation happens. He is a once farmer from the West Coast of Wales. His crops were destroyed two years running by unprecedentedly hostile weather. The only way for effective change now he says, is the way of Ghandi, the Freedom Riders, Martin Luther King, and Nelson Mandala; ${ }^{3}$ that is civil disobedience. He is not uninformed: he holds two Doctorates from Cambridge - he proudly says in "civil disobedience", and 'rebellion'. His goal is to avert accelerating climate breakdown through passive rebellion. Fossil fuel industries are a principal target and their shareholders, through nonviolent resistance and civil disobedience. In 2018 one hundred U.K. academics signed a call to action and XR was launched at the end of October by Roger Hallam, Gail Bradbrook, Simon Bramwell and other activists from the group Rising Up!

The movement is unusual in that a large number of activists have pledged to be arrested and are prepared to go to prison. Extinction Rebellion intends to rally support worldwide around a common urgency to tackle climate breakdown. With the rationale that overwhelming arrests for passive protest; such as in London in November 20 I 8 , will clog the prisons and tie up the judiciary. Then, bail or release are the quicker options. As Roger Hallam said in Penzance, Cornwall, UK.

Penzance is a small sea-side town, once a healthy, proud fishing port, now ratty surf capital of the UK. The audience filled the small school gymnasium. Hallam was articulate and personable, talking calmly about taking time out in prison, reading and getting more informed and organised. He tells appalling stories about $75 \%$ of the Arctic Ice having melted in the last 30 years. He also mentions that the man who discovered the (first) Hole in the Ozone Layer in the nineties asserts that in the year 2022 - there will be no permanent ice in the Arctic at all. Now there is a second Northern hole in the ozone, to balance the one over New Zealand.

The more sensitive end of the human spectrum traditionally, is that of the artist, and now they are needed more and more to register in more significant ways than as entertainment, or investment, or vogue-ism. Invention, imagination, and courage, and intelligence, and concern are desperately needed. We have to help do the apparently impossible for this planet, now with less ego-constructs. This essay is being written within the context of an art-school ... within the context of more data than we as humans can cope with, and more disaster looming than we can have ever begun to contemplate.

The plight of extinction for unimaginable numbers of creatures, is easy to sympathise with as it starts with recognising imminent tragedy of those cuddly or cute varieties: also those believed to enjoy superior powers of intelligence. For then there is a possibility of empathising with a supposition of shared emotions and a presumption of understanding. It then becomes a tragedy to share, as we see vast slaughter, singular cruelties and ignorant behaviours whittle species down by the score, by the thousands. Truth of the matter is that there has been within evolution a selfchecking balance and interdependence which allows the physics of the planet to be maintained and effect necessary changes or evolution to proceed at a slow and steady pace. In the twenty-first century the velocity of change has moved beyond all imagination, and the slow and steady self-regulating body is now out of balance to an impossible degree. The thinking of James Lovelock in 1978, in a book Gaia ${ }^{4}$ which considered the evolution of the ecologies of the planet - as a whole organism, was written by a serious independent scientist. It functions as a model for understanding a wider ecology and is a broad, useful simile, to stress the inter-relatedness of things and systems.

The current pandemic we are attempting to survive, illustrates the manner in which the breakdown of civil structures mimics the breakdown of natural structures, allowing an insight into the relationship of those entities we chose to see as partitioned, as separate. The Earth as organism seems not so far fetched. Cracks in political structures are being perceived everywhere. Production, supply and commerce are in confusion as panic and urgency are driven by fear. Human hegemony is no defence against the disaster of the virus; no stratum nor individual is exempt. Habituated forms of doing business, of educating, of communicating, of living, are in flux. We are at a global hiatus.

Reliance on overseas producers has left individual nations weak, prone to disaster when products or services are withheld. Global capitalism is held together by agreements outside national needs, bargains made to suit the few, 
for reasons that do not benefit any population. Cold War politics of tit-for-tat disagreements attempt to patch the impossible relationships between disparate governments, piratical industries and demanding investors. The machinery of global commerce appears to thrive, promoting talk of global economy while communities are destroyed, and nations wither. As companies streamline, close, modify; jobs are lost, skills are forgone and responsibilities forgotten; those of Governments to the people and of industries to the Governments. A peculiar interactive energy ensues, in concert destructively with other movements around the globe. There is a multitudinous wiggling with a vague sense of causality, but the major benefits are for the shareholders, and unimaginable benefits for the drivers of these floatation tanks. Jeff Bezos the richest man in the world due to a fortunate idea which developed into Amazon; in the first weeks of the current COVID 19 epidemic, grew twenty-four billion U.S. dollars richer overnight due to stock changes. Through various covenants tax is not an issue for this man, nor is it for most world billionaires, of which there are around thirty-six.

Reflexive trading with the fever of a major poker game, disallows time to think about the greater good. Which we are unused to recognising this as a basic necessity, and so we hurtle on. Climate controls, emissions standards, are all too difficult, shareholders must be appeased and gratified to ever greater expectations. International agreements or government policies entered into the statutes by one government can be easily undone by another. We see the rise of autocrats buoyed together by an entertaining fabric of lies, performing to a balcony of grinning investors oblivious of the real world. Lies are the new truth. The entire natural world is being destroyed with all of us mammals, by homo-sapiens.

The present viral emergency, although it has taken immediate focus off solving the climate emergency, has allowed us to see that that the world can shut down, for some things to be rearranged, even resolved. This disruption is a useful pause for thought and could be a time for rearranging other things that are broken; such as voter registration, and election structures in the United States. Things which have been taken as 'givens' too, but only having habituated meaning - like 'democracy' and 'civil rights', which are ill-defined often misunderstood. They need to be re-debated, meanings clarified, reasons understood. The danger is that this pause can also be taken as another business opportunity, or another means to use fear against the populace, as is happening. However the most shocking news to me recently was when the Secretary General of the United Nations on 23 March 2020 - António Guterres, urged warring parties across the world to lay down their weapons in support of the bigger battle against COVID-19. The most shocking, absurd, and terrifying declaration to all the world in world history! This must mean something. But this virus is not to be defeated by instant world peace, unless immediate climate cooperation takes place, for behind the danger of serial epidemics lies the root cause of global warming. Climate crisis: means so many demands to be examined, things which need to be questioned as being useful. Or recognised as not at all useful like cruise-ships.

After investigating air quality on cruises, Johns Hopkins University professor Ryan David Kennedy told CNN their onboard air pollution was "comparable to concentrations measured in polluted cities, including Beijing and Santiago". Yet the health risks posed by cruise ship emissions do not only affect their passengers. As Forbes reports, a single cruise ship emits daily pollution equal to a million cars. One passenger's carbon footprint triples in size when taking a cruise. Currently there are 90,000 passengers quarantined in U.S. waters alone, unable to be cleared for landing. The Royal College of Physicians reported that the premature deaths of about 40,000 shore-bound Britons every year are linked to air pollution, the cruise and shipping industry being significantly responsible. Those vessels also expel enormous quantities of discharge into the ocean. They are notorious for covering up that they illegally dump sewage, garbage and fuel waste - often into protected waters, and burn cheap sulfurous fuel, illegal for use in land vehicles. Carnival Corp's environmental violations date back to 1993 and are still pending. We are at war with the planet still. In the manner of pillaging nineteenth century colonists, but we have forgotten this global warfare also costs. Hugely. The solution as Hallam states requires restraint and sacrifice. Mahatma Gandhi knew this. The period of irresponsible decadence we have enjoyed has to be paid for now, with more austerity and more restraint in a far more equitable way, as was done during and after the Second World War. Because the causal is becoming more visible, and there is a strong chance we have only ten years before waves of mass starvation. 
All attempts at making art have a context of creation, and necessarily are indicative of concerns-of-that-time with those attempts to think-with-imagination. All attempts to deliver a shudder or otherwise, from the present toward the enormity of time, can only tremble lightly against the truths which become more evident and more terrible every actual day. Progress in anything anywhere, is a moot point at this time, definitely within the multiple worlds designated or colonised, as a.r.t. Nevertheless we who have chosen - must continue to make whatever noises we can however we can, and for those noises to gather and reveal significance over time, poetic allusion has to prevail. I should like to point out to the Academy at large, that the activity of any questing-artist throughout all time, is 'research' of a primal nature; independent, personal, inventive out of necessity and political in essence. So much so, that that word has scarcely been used throughout our history, as it is intrinsic to the practice: as is physical and mental labour, and invention beyond the norm. This is why in the past we have had those magnificent, flawed, sensitive, and sensible structures which have stood proudly as independent art-schools: umbrellas for contentious experiment, invention, challenge, independent thinking, experience and debate; incubators of sensibility and even prescience. Never schools of artifice or manipulated egregious 'taste', not apologetic factories for commodified markers of rank, nor bogus academies of commerce meeting the hegemonic expectations of the self-propagating education industry.

Whether evident or not, a realisation of history will direct or encourage speculation or questioning after evaluation, of the experience-of-being, in a designated space, or more importantly as a part of Humanity. Sensing and realising the elements of content; ensures provocation or revelation over time. This experience unravels slowly within the consciousness of the other through that a.r.t. Sensing the disquiet in gaps of logic, sensing scale or space in that experience; leads over time to realisations within the other person, of congruity, awareness of similarity, of dissonance, or social sympathy, of anger. Or even rebellion.

Sensational!

For what more can we hope?

Adrian Hall has been an innovating artist for sixty years. He has practised in Europe, the United States of America, Northern Ireland, Eire, Australia, Japan, and for the last sixteen years has lived and worked from Aramoana, Otago. Born in Cornwall, UK. 
I Rachel Carson, Silent Spring, (Houghton Miffin Co. Anniversary Edition October 22, 2002 Originally published September 27, 1962.)

2 Michael Field, The Catch: How Fishing Companies Reinvented Slavery and Plunder the Oceans, (Awa Press November I, 20I4) (Of particular relevance to N.Z. Readers.)

3 Nelson Mandela, Long Walk to Freedom, (Abacus; New Ed edition 12 Oct. 1995).

4 James Lovelock, Gaia, Published November 23rd 2000 by Oxford University Press, USA (first published 1979) Original Title: Gaia: A New Look at Life on Earth.

\section{OTHER SOURCES OF INFORMATION}

Greta Thunberg at the United Nations, 2019, https://www.youtube.com/watch?v=KAlsdgTPJpU

Greta With Arnold Schwarzenegger, the Austrian Climate Conference, May 2019

https://www.youtube.com/watch?v=XkOdMRUQkN8

Greta Thunberg Earth Day April 22, 2020

https://www.theguardian.com/environment/2020/apr/22/earth-day-greta-thunberg-calls-for-new-path-afterpandemic?CMP=Share_AndroidApp_Tweet

Mad Men, $\mathrm{HBO}$

https://www.theguardian.com/environment/radical-conservation/20I5/oct/20/the-four-horsemen-of-the-sixth-mass-extinction https://www.theguardian.com/environment/2020/mar/I 0/climate-emergency-global-action-way-off-track -says-un-ead-coronavirus

https://www.newyorker.com/podcast/the-new-yorker-radio-hour/the-coronavirus-and-climate-change-the-great-crises-of-our-time - podcast

Peace and Security - In an appeal issued on Monday, UN Secretary-General António Guterres urged warring parties across the world to lay down their weapons in support of the bigger battle against COVID- 19: the common enemy that is now threatening all of humankind. 23 March 2020 https://news.un.org/en/story/2020/03//059972

https://www.theguardian.com/us-news/2019/dec/1 I/donald-trump-jr-mongolia-rare-endangeredsheep-permit?CMP=share_btn_link

https://www.newsweek.com/donald-trump-jr-alaska-grizzly-bear-hunting-permit-pure- luck-draw-|48856 Is

Roger Hallam, XR - The Time Is Now, https://www.youtube.com/watch? $v=s 2 s Q 3 X D \times q 21$

Sam Harris debating Jordan Peterson https://www.youtube.com/watch?v=jey_CzlOfYE

https://www.dailykos.com/stories/2020/4/27/1940788/-Turns-out-Carnival-Cruise-Line-got-a- backdoor-multibillion-dollar-bailoutfrom-the-federal-reserve?utm_campaign=trending 


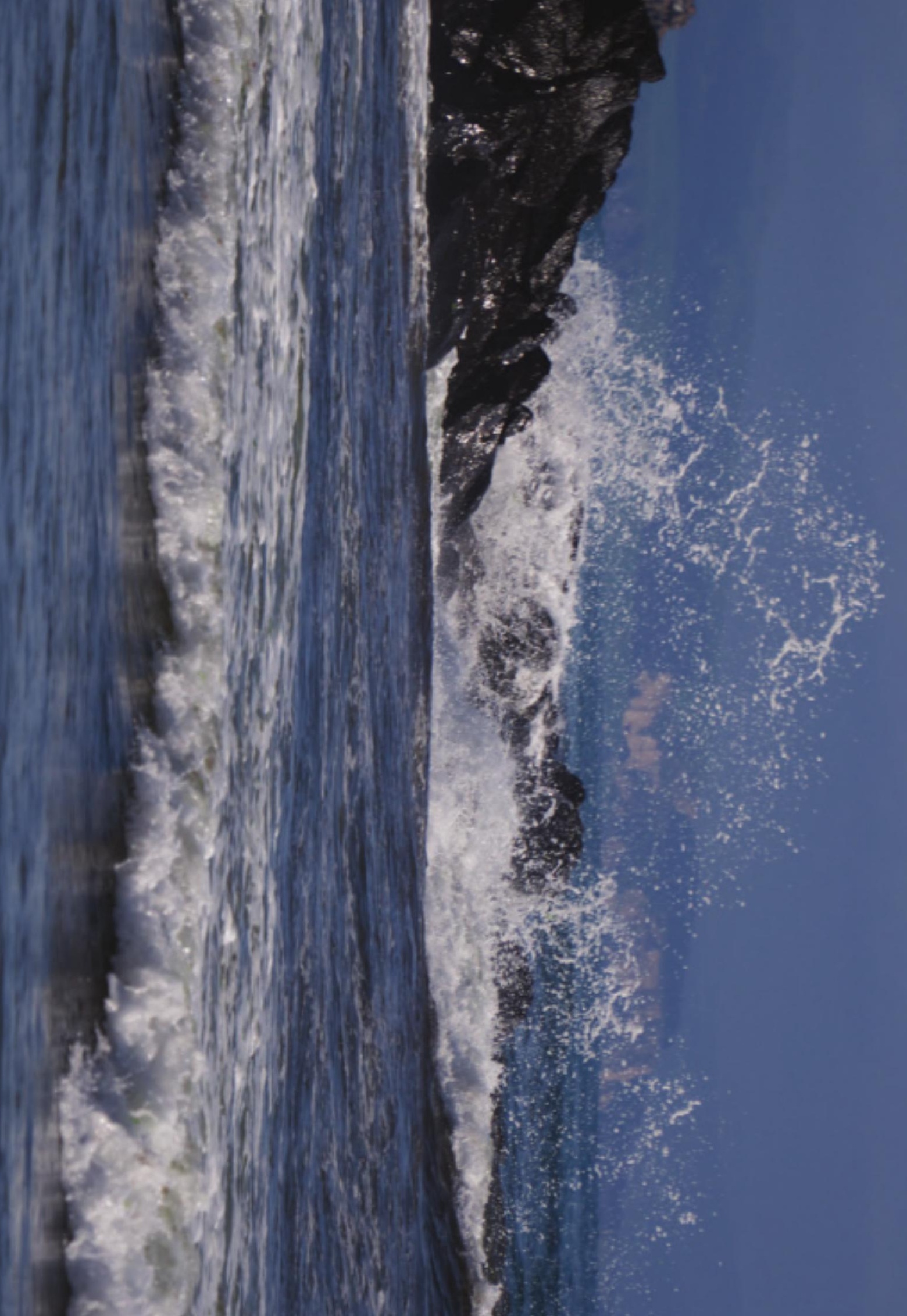




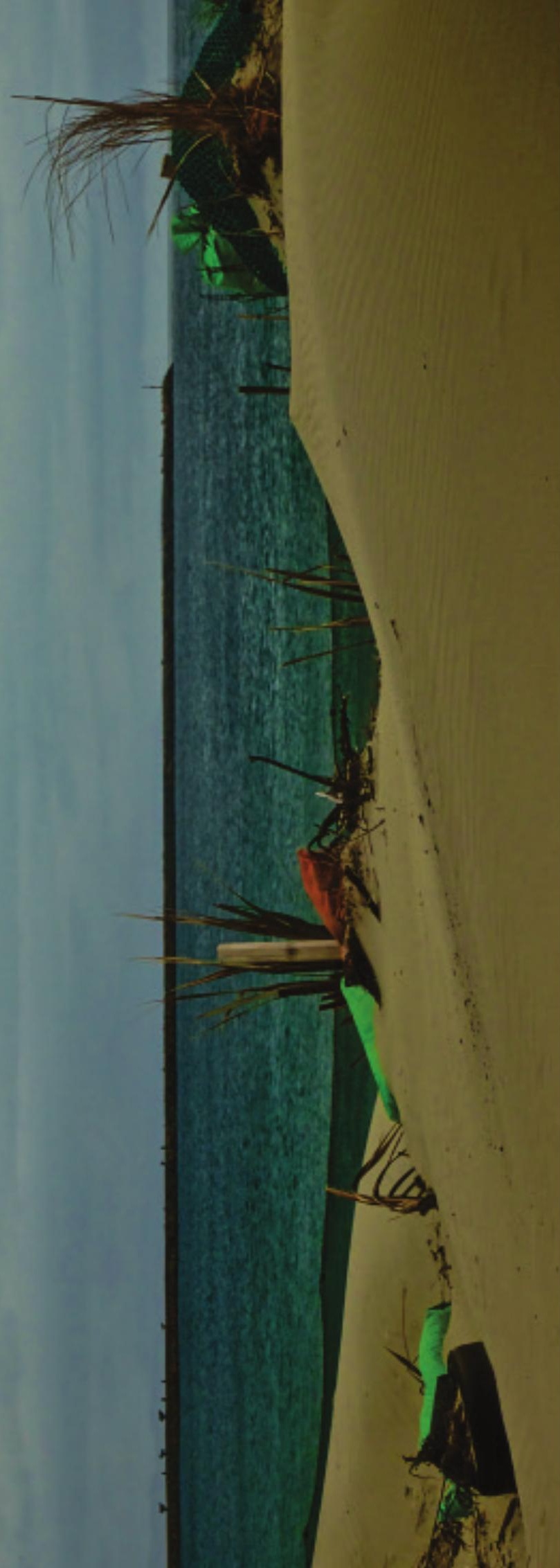

